\title{
Job Stress and Intent to Stay at Work among Registered Female Nurses Working in Thai Hospitals
}

\author{
Orawan KaEwBoONCHOO ${ }^{1}$, Boonrord YingYUAD ${ }^{2}$, Tassanee RAWIWORRAKUL ${ }^{1}$ and \\ Adchara JINAYON ${ }^{3}$
}

${ }^{1}$ Faculty of Public Health, Mahidol University, Thailand, ${ }^{2}$ Sena Hospital, Thailand and ${ }^{3}$ Faculty of Nursing, Huachiew Chalermprakiet University, Thailand

\begin{abstract}
Job Stress and Intent to Stay at Work among Registered Female Nurses Working in Thai Hospitals: Orawan KaEWBOONCHOO, et al. Faculty of Public Health, Mahidol University, Thailand-Objectives: Job stress is one of the factors that increase the likelihood of turnover. Intent to leave work is one of the most accurate predictors of turnover. This crosssectional study was created to evaluate the intent of nurses working at hospitals to continue working and to determine the relationship between job stress and intent to stay at work. Methods: The subjects were 514 female hospital nurses aged 21-58 years old, who had worked full time at the study hospitals for at least 1 year. Data were collected using a self-administered questionnaire, which included sections on demographic characteristics, the Thai version of the Job Content Questionnaire (JCQ), and intent to stay at work. Multiple regression analysis was used to identify factors related to intent to stay at work. Results: The prevalences of high job strain and low intent to stay at work were 17.5 and $22.4 \%$, respectively. The mean (SD) scores of the nurses for psychological job demand, decision latitude, workplace social support, and intent to stay at work were 33.5 (4.4), 70.7 (6.9), 23.8 (2.8), and 14.6 (2.9), respectively. Multiple regression analysis indicated that intent to stay at work was significantly correlated with only supervisor support among the nurses with high-strain jobs and with coworker support in nurses with active jobs. Conclusions: The findings suggest that different job types need different sources of social support in the workplace. Proactive steps by nurse managers to increase workplace social support might lead to an increase in intent to stay and reduce nursing turnover in hospitals and possibly other settings.
\end{abstract}

(J Occup Health 2014; 56: 93-99)

Received Aug 23, 2012; Accepted Nov 17, 2013

Published online in J-STAGE Jan 16, 2014

Correspondence to: O. Kaewboonchoo, Faculty of Public Health, Mahidol University, 420/1 Rajvithi Road, Rajthevee, Bangkok 10400, Thailand (e-mail: orawan.kae@mahidol.ac.th)
Key words: Intent to stay, JCQ, Job stress, Nurse, Social support

Current nursing shortages and high job turnover among nurses are of great concern for developed and developing countries. They are particularly important in hospitals where nurse shortages have an impact on patient safety, quality of care, and health-care organizations ${ }^{1-4)}$. In Thailand, the exit rate of nurses is $4.4 \%$ per year and expected to increase to over $15 \%$ by the year $2020^{5}$. A previous study found that $30 \%$ of hospital nurses in Thailand intend on leaving the profession $^{6}$. This may result in a nursing shortage, which will affect the health-care system in Thailand.

Intent to leave employment is one of the most accurate predictors of turnover. It is the penultimate stage of the turnover process prior to actually leaving ${ }^{7}$. Understanding the factors that influence nurses' intent to stay at work could increase the retention of nurses and decrease the turnover rate ${ }^{8}$.

Job stress is one factor that increases the likelihood of turnover, which is costly as well as destructive to nurse and patient outcomes ${ }^{9}$. Health-care workers have been recognized as experiencing occupational stress $^{10,11)}$. Many nurses continue to leave their workplaces before they reach the age of retirement due to poor work conditions such as heavy workload, low job control, and low workplace social support ${ }^{12)}$.

The Job Content Questionnaire (JCQ) has been widely used to assess psychosocial conditions in the workplace $^{13)}$. The JCQ examines decision latitude, psychological job demands, and workplace social support. This model hypothesizes that the combination of high psychological job demands and low worker decision latitude causes job stress. Low workplace social support would increase the risk $^{14)}$. The JCQ has been used in epidemiological studies on job stress in various occupations. The stress-disease link has been explored for cardiovascular diseases ${ }^{15-17)}$, muscu- 
loskeletal disorders ${ }^{18,19)}$, and mental health ${ }^{6,20,21)}$. The relationship between job stress and turnover intention among nurses in European countries, Canada, and China has also been studied ${ }^{22,23)}$. However, there is a lack of information on the relationship between job stress and intent to stay at work among nurses in Thailand.

The purpose of this study was to evaluate the intent of nurses in Thai hospitals to stay at work and to determine the relationship between job stress and intent to stay at work among nurses.

\section{Subjects and Methods}

\section{Subjects}

The subjects involved in the survey included 526 female registered nurses (RN) working in two medium- and large-sized government hospitals in Phranakhon Si Ayutthaya Province, Thailand. RNs who had been working full time at the study hospitals for at least 1 year were included in the study. In February and March 2010, the nursing director of each hospital was asked to distribute self-administered questionnaires, envelopes for return of the questionnaires, and documents explaining the purpose of the study, the privacy policy, and informed consent forms. Participants were asked to return completed questionnaires within one month of their distribution. The questionnaires were returned in sealed envelopes, which were given to the nurses in charge at each station. After excluding the questionnaires with missing values and those completed by male nurses, data from 514 questionnaires were analyzed. The response rate was $97.7 \%$. Informed consent was obtained from all subjects. The research protocol was approved by the Ethics Committee of the Faculty of Public Health, Mahidol University.

\section{Instrumentation}

The survey instrument was a self-administered questionnaire with sections on demographic characteristics, job stress, and intent to stay at work.

Part 1 was on the general characteristics of the respondents. It was composed of questions on sex, age, education level, monthly income, marital status, work experience, work hours per day, job position, and shift work.

Part 2 was on job stress. The Thai version of the Job Content Questionnaire (JCQ) ${ }^{24)}$ was used. This consisted of 22 questions measuring 3 dimensions: psychological job demand, decision latitude, and workplace social support. Psychological job demand and decision latitude scales were used to measure job strain. The psychological job demand scale was measured by 5 items. The decision latitude scale was the sum of two subscales, skill discretion, measured by 6 items, and decision authority, measured by 3 items. The social support scale was the sum of 2 subscales, support from supervisors and support from co-workers, each measured by 4 items. For each item, the response was recorded on a 4-point Likert-type scale, with 1 representing totally disagree, 2 representing disagree, 3 representing agree, and 4 representing totally agree. For each scale, a sum of weighted item scores was calculated. The range for psychological job demand was 12-48, the range for decision latitude was 24-96, and the range for social support was 8-32. The Cronbach's alpha coefficient for the JCQ scales and subscales ranged between 0.322-0.899 (Table 1).

To determine the prevalence of job strain (high psychological job demand and low decision latitude), psychological job demand and decision latitude scores were dichotomized by median cutoff point to obtain "high ( $\geq$ median score)" and "low (<median score)" values for each scale. Jobs were divided into four types: active jobs (high psychological job demand and high decision latitude), high-strain jobs (high psychological job demand and low decision latitude), passive jobs (low psychological job demand and low decision latitude), and low-strain jobs (low psychological job demand and high decision latitude $)^{13)}$.

Part 3 was on intent to stay at work. This was measured by four items that asked about intent to stay at work from the perspectives of the past, present,

Table 1. Cronbach's alpha coefficients $(\alpha)$, means, SD, and ranges of the JCQ subscale and intent to stay

\begin{tabular}{lccccc}
\hline Scale & No. of items & $\alpha$ & Mean & SD & Range \\
\hline Psychological job demand & 5 & 0.442 & 33.5 & 4.4 & $21-48$ \\
Decision latitude & 9 & 0.595 & 70.7 & 6.9 & $54-92$ \\
$\quad$ Skill discretion & 6 & 0.538 & 35.8 & 3.6 & $24-46$ \\
$\quad$ Decision authority & 3 & 0.322 & 34.9 & 4.6 & $24-48$ \\
Workplace social support & 8 & 0.853 & 23.8 & 2.8 & $13-32$ \\
$\quad$ Supervisor support & 4 & 0.858 & 11.5 & 1.8 & $5-16$ \\
$\quad$ Coworker support & 4 & 0.899 & 12.3 & 1.5 & $4-16$ \\
Intent to stay & 4 & 0.861 & 14.6 & 2.9 & $4-20$ \\
\hline
\end{tabular}


and future. The respondents were asked to indicate their agreement with the following four items on a five-point scale, ranging from 1 (totally disagree) to 5 (totally agree):

(1) "It has been my intention to work as a nurse from when I started until now"

(2) "It is my intention to continue to work as a nurse in the future"

(3) "It is my intention to continue to work in my current job as long as I can"

(4) "I expect to stay in the nursing profession"

The intent to stay at work was dichotomized by mean cutoff point to obtain "high ( $\geq$ mean score)" and "low (<mean score)" values. The subjects considered to have an intention to stay include those who answered unsure for all four items. The Cronbach's alpha coefficient for intent to stay at work in this study was 0.861 (Table 1 ).

\section{Data analyses}

All data were analyzed using SPSS for Windows Version $11.5^{25)}$. Descriptive statistics such as the frequency, percentage, and mean were used to describe the studied variables. The independent t-test was used to compare means. Associations between independent variables and intent to stay at work were analyzed using multiple linear regression analysis, with intent to stay at work as the dependent variable and general characteristics of the respondents and job stress as independent variables.

\section{Results}

The demographics of the nurses are presented in Table 2. Of the total $(n=514)$ respondents, most were 30-39 years old $(46.3 \%)$. The average age was $37.5 \pm 8.3$ years. More than half $(56.8 \%)$ were married; $62.3 \%$ were single family; $51.2 \%$ worked in wards; $94.9 \%$ were staff nurses; and $74.7 \%$ worked some night shifts. Most had 11-20 years of nursing experience $(40.4 \%)$, with the average work experience being $15.7 \pm 8.5$ years; $74.5 \%$ worked 8 hours per day. The average income per month for the nurses was 26,363.9 $\pm 9,038.36$ Thai Baht. Most had a monthly income in the range 20,001-30,000 Thai Baht $(38.3 \%)$.

Mean scores of psychological job demand ranged

Table 2. Characteristics of the subjects $(\mathrm{N}=514)$

\begin{tabular}{|c|c|c|c|}
\hline Variables & & Number & $\%$ \\
\hline Age (year) & $\begin{array}{l}20-29 \\
30-39 \\
40-49 \\
50- \\
\text { Mean=37.5, SD=8.3, Min=21, Max=58 }\end{array}$ & $\begin{array}{l}79 \\
238 \\
152 \\
45\end{array}$ & $\begin{array}{l}15.4 \\
46.3 \\
29.6 \\
8.7\end{array}$ \\
\hline Marital status & $\begin{array}{l}\text { Single } \\
\text { Married } \\
\text { Widowed/divorced }\end{array}$ & $\begin{array}{l}195 \\
292 \\
27\end{array}$ & $\begin{array}{l}37.9 \\
56.8 \\
5.3\end{array}$ \\
\hline Family type & $\begin{array}{l}\text { Single } \\
\text { Extended }\end{array}$ & $\begin{array}{l}320 \\
194\end{array}$ & $\begin{array}{l}62.3 \\
37.7\end{array}$ \\
\hline Workplace & $\begin{array}{l}\text { Out patient department } \\
\text { Surgery/delivery/emergency room } \\
\text { Ward }\end{array}$ & $\begin{array}{l}60 \\
191 \\
263\end{array}$ & $\begin{array}{l}11.7 \\
37.1 \\
51.2\end{array}$ \\
\hline Position & $\begin{array}{l}\text { Administrative } \\
\text { Clinical nurses }\end{array}$ & $\begin{array}{l}26 \\
488\end{array}$ & $\begin{array}{l}5.1 \\
94.9\end{array}$ \\
\hline Shift work & $\begin{array}{l}\text { With night work } \\
\text { Without night work }\end{array}$ & $\begin{array}{l}384 \\
130\end{array}$ & $\begin{array}{l}74.7 \\
25.3\end{array}$ \\
\hline $\begin{array}{l}\text { Years of service in } \\
\text { nursing (year) }\end{array}$ & $\begin{array}{l}1-10 \\
11-20 \\
>20 \\
\text { Mean=15.7, } \mathrm{SD}=8.5, \mathrm{Min}=1, \mathrm{Max}=52\end{array}$ & $\begin{array}{l}153 \\
208 \\
153\end{array}$ & $\begin{array}{l}29.8 \\
40.4 \\
29.8\end{array}$ \\
\hline $\begin{array}{l}\text { Working hours } \\
\text { per day (hour) }\end{array}$ & $\begin{array}{l}7-8 \\
>8 \\
\text { Mean=10.0, SD=3.5, Min=8, } \operatorname{Max}=16\end{array}$ & $\begin{array}{l}383 \\
131\end{array}$ & $\begin{array}{l}74.5 \\
25.5\end{array}$ \\
\hline $\begin{array}{l}\text { Monthly income } \\
\text { (baht) }\end{array}$ & $\begin{array}{l}-20,000 \\
20,001-30,000 \\
30,001- \\
\text { Mean }=26,363.91, \mathrm{SD}=9,038.36, \mathrm{Min}=10,000, \mathrm{Max}=60,000\end{array}$ & $\begin{array}{l}188 \\
197 \\
129\end{array}$ & $\begin{array}{l}36.6 \\
38.3 \\
25.1\end{array}$ \\
\hline
\end{tabular}


from 21 to 48 with a mean of 33.5 and an SD of 4.4. Decision latitude scores ranged from 54 to 92 with a mean of 70.7 and an SD of 6.9. Social support scores ranged from 13 to 32 with a mean of 23.8 and an SD of 2.8. Intent to stay at work scores ranged from 4 to 20 with a mean of 14.6 and an SD of 2.9 (Table 1).

The prevalences of high job strain and low intent to stay at work were $17.5 \%$ and $22.4 \%$, respectively (Table 3). Nurses who perceived high job demands (high strain and active job) and high social support had a significantly higher mean scores for intent to stay at work than those with low social support (Table 4).

Table 5 is a correlation matrix for the study variables. Intent to stay at work was significantly correlated with psychological job demands and social support at work. However, multiple regression analysis indicated that intent to stay at work was significantly correlated with only supervisor support among the nurses with high-strain jobs and with coworker support in nurses with active jobs (Table 6).

\section{Discussion}

The shortage of nurses has become a major concern in recent years because of its impact on the quality of nursing care and the health system. Turnover is a major cause of nursing shortages. Many factors influence turnover among nurses. Job stress is one of the factors that increase the likelihood of turnover ${ }^{8)}$. This

Table 3. Prevalence of job and intent to stay at work among 514 respondents

\begin{tabular}{lcc}
\hline Type of job and intent to stay & Number & $\%$ \\
\hline High strain & 90 & 17.5 \\
Non-high strain & 424 & 82.5 \\
$\quad$ Low strain & 125 & 24.3 \\
$\quad$ Active & 187 & 36.4 \\
$\quad$ Passive & 112 & 21.8 \\
Intent to stay at work & & \\
$\quad$ High & 399 & 77.6 \\
$\quad$ Low & 115 & 22.4 \\
\hline
\end{tabular}

study evaluated job stress and intent to continue working among hospital nurses.

The prevalence of a high amount of strain among female hospital nurses was $17.5 \%$, which was lower than that of Thai workers $(27.5 \%)$ in a rubber-glove factory, which included both male and female work$\mathrm{ers}^{26)}$. The differences in prevalence of a high amount of strain may due to the different of sample properties among the two groups. The mean score for decision latitude among nurses was higher than that among the rubber-glove workers. The subjects seemed to have more freedom to manage their own work in taking care of patients; however, the workers were required to follow the orders of supervisors. These factors may contribute to the difference in decision latitude between nurses and workers. Not much difference has been found between the mean JCQ scores of Thai, Chinese, and Taiwanese nurses. However, the decision authority subscale was lowest for Chinese nurses $^{27,28)}$

In this study, $77.6 \%$ of nurses reported intent to stay at work. However, $22.4 \%$ indicated they did not intend to stay at their current job. The nurses who perceived high job demands tend to leave their jobs. Nurses who perceived high job demands (high strain and active job) and high workplace social support had a significantly higher mean score for intent to stay at work than those with high job demands and low social support in the workplace. Data analysis indicated that the intent to stay at work was independently significantly associated with coworker support among active jobs and associated with supervisor support among high-strain jobs. Several studies reported the relation between job stress in terms of perceived high job demands and lack of social support and turnover intention among nurses in Canada and Taiwan ${ }^{22,23)}$. Many studies have reported a relationship between supervisor support and intent to stay at work ${ }^{29-33)}$. The nurses who left their positions reported that they were unhappy with management support and lack of support from the hospital ${ }^{34}$. However, in this study, new findings were found when job types were considered. It was found that the intent to stay at work

Table 4. Comparison mean of intent to stay between high and low social support in each type of job

\begin{tabular}{llll}
\hline $\begin{array}{l}\text { Type of job } \\
\text { according to JCQ }\end{array}$ & $\begin{array}{l}\text { High social support } \\
\text { Mean (SD), n }\end{array}$ & $\begin{array}{l}\text { Low social support } \\
\text { Mean (SD), n }\end{array}$ & $p$-value \\
\hline High strain & $15.1(2.2), 43$ & $13.7(3.1), 47$ & $0.021^{*}$ \\
Low strain & $14.8(3.3), 101$ & $14.8(2.4), 24$ & 0.932 \\
Active & $15.0(2.9), 130$ & $13.5(3.4), 57$ & $0.002^{* *}$ \\
Passive & $14.7(2.5), 82$ & $14.9(2.6), 30$ & 0.684 \\
\hline
\end{tabular}

${ }^{*} p<0.05 ; * * p<0.01$. 
Table 5. Correlations matrix for intent to stay at work, job strain, and characteristics

\begin{tabular}{|c|c|c|c|c|c|c|}
\hline & 1 & 2 & 3 & 4 & 5 & 6 \\
\hline 1. Intent to stay at work & 1 & & & & & \\
\hline 2. Job demand & $-0.082 *$ & 1 & & & & \\
\hline 3. Decision latitude & 0.024 & $0.143 * *$ & 1 & & & \\
\hline 4. Supervisor support & $0.080^{*}$ & $-0.212 * *$ & $0.215^{* *}$ & 1 & & \\
\hline 5. Coworker support & $0.150 * *$ & $-0.078^{*}$ & $0.322 * *$ & $0.376^{* *}$ & 1 & \\
\hline 6. Work experience & -0.006 & -0.028 & 0.050 & $-0.127 * *$ & -0.033 & 1 \\
\hline 7. Age & -0.007 & -0.023 & 0.060 & $-0.086^{*}$ & 0.031 & $0.962 * *$ \\
\hline 8. Marital status & -0.023 & 0.009 & 0.030 & -0.051 & -0.036 & $0.287 * *$ \\
\hline 9. Job position & 0.017 & 0.028 & 0.029 & $-0.111^{* *}$ & -0.009 & $0.424 * *$ \\
\hline 10. Shift work & -0.053 & 0.003 & $-0.171 * *$ & 0.038 & $-0.144 * *$ & $-0.489 * *$ \\
\hline 11. Salary & -0.012 & -0.031 & $0.117 * *$ & -0.067 & 0.007 & $0.669 * *$ \\
\hline \multirow[t]{2}{*}{ 12. Work hour per day } & 0.012 & $0.103^{*}$ & 0.069 & -0.036 & -0.052 & $-0.247 * *$ \\
\hline & 7 & 8 & 9 & 10 & 11 & \\
\hline \multicolumn{7}{|l|}{ 1. Intent to stay at work } \\
\hline \multicolumn{7}{|l|}{ 2. Job demand } \\
\hline \multicolumn{7}{|l|}{ 3. Decision latitude } \\
\hline \multicolumn{7}{|l|}{ 4. Supervisor support } \\
\hline \multicolumn{7}{|l|}{ 5. Coworker support } \\
\hline \multicolumn{7}{|l|}{ 6. Work experience } \\
\hline 7. Age & 1 & & & & & \\
\hline 8. Marital status & $0.274 * *$ & 1 & & & & \\
\hline 9. Job position & $0.433 * *$ & $0.140 * *$ & 1 & & & \\
\hline 10. Shift work & $-0.523 * *$ & $-0.092 *$ & $-0.220 * *$ & 1 & & \\
\hline 11. Salary & $0.699 * *$ & $0.242 * *$ & $0.388 * *$ & $-0.291 * *$ & 1 & \\
\hline 12. Work hour per day & $-0.252 * *$ & -0.012 & $-0.100 *$ & $0.280 * *$ & $-0.104 * *$ & \\
\hline
\end{tabular}

${ }^{*} p<0.05 ; * * p<0.01$

Table 6. Factors related to intent to stay at work according to the JCQ job types among Thai nurses by multiple regression analysis

\begin{tabular}{|c|c|c|c|c|c|c|c|c|}
\hline & \multicolumn{2}{|c|}{ High strain } & \multicolumn{2}{|c|}{ Low strain } & \multicolumn{2}{|c|}{ Active } & \multicolumn{2}{|c|}{ Passive } \\
\hline & $\begin{array}{c}\text { Standardized } \\
\text { coefficient }\end{array}$ & $p$-value & $\begin{array}{c}\text { Standardized } \\
\text { coefficient }\end{array}$ & $p$-value & $\begin{array}{c}\text { Standardized } \\
\text { coefficient }\end{array}$ & $p$-value & $\begin{array}{c}\text { Standardized } \\
\text { coefficient }\end{array}$ & $p$-value \\
\hline Job demand & -0.059 & 0.637 & -0.158 & 0.099 & 0.012 & 0.872 & -0.092 & 0.345 \\
\hline Decision latitude & -0.072 & 0.526 & -0.160 & 0.146 & 0.102 & 0.191 & -0.099 & 0.328 \\
\hline Supervisor support & 0.273 & $0.034 *$ & -0.019 & 0.862 & 0.071 & 0.348 & 0.002 & 0.989 \\
\hline Coworker support & 0.138 & 0.220 & 0.082 & 0.465 & 0.160 & $0.050^{*}$ & 0.076 & 0.474 \\
\hline Work experience & -0.099 & 0.850 & -0.214 & 0.409 & 0.456 & 0.118 & 0.345 & 0.485 \\
\hline Age & -0.056 & 0.917 & 0.395 & 0.165 & -0.476 & 0.132 & -0.288 & 0.575 \\
\hline Marital status & -0.075 & 0.492 & -0.037 & 0.712 & 0.021 & 0.793 & 0.040 & 0.693 \\
\hline Job position & 0.089 & 0.466 & -0.080 & 0.457 & -0.052 & 0.506 & 0.032 & 0.554 \\
\hline Shift work & -0.038 & 0.770 & -0.048 & 0.694 & -0.157 & 0.088 & -0.007 & 0.948 \\
\hline Salary & 0.125 & 0.477 & -0.026 & 0.849 & 0.026 & 0.800 & -0.192 & 0.162 \\
\hline Work hour per day & 0.020 & 0.868 & 0.067 & 0.509 & -0.043 & 0.592 & 0.079 & 0.601 \\
\hline
\end{tabular}

$* p<0.05$. 
was significantly associated with different sources of social support. Among nurses with high-strain jobs, supervisor support was found to be more important than coworker support, whereas among nurses with active jobs, coworker support was more important than supervisor support. Stress levels are reduced by supervisor and coworker support ${ }^{35}$. Social support is an important buffer against the negative effects of stress such as intent to leave work ${ }^{36}$. Based on the outcomes of this study, it is suggested that social support in the workplace is important and related to intent to stay at work in the professional of nursing. However, these results should be cautiously generalized to Thai nurses or those in other countries.

The limitations of our study included (a) that there may be reporting bias for self-reported job stress, as subjects may be affected by recollection and recall; (b) that the cross-sectional study design limits the ability to make valid causal interpretations of the findings; (c) that since the sources of stress are multiple, other stressors, such as organizational factors, job satisfaction, and non-job factors cannot be excluded; (d) that the female nurses were selected from one province in a middle region of Thailand, so the results may not be representative of all female nurses in Thailand; and (e) that relatively lower Cronbach's alpha values were found for a couple of subscales. The acceptable value of Cronbach's alpha ranges from $0.70-0.95^{37,38)}$. The Cronbach's alpha coefficients of the Thai version of the JCQ for psychological job demands and decision latitude were relatively low, which might be due to the heterogeneity of the studied sample. Therefore, the study results based on these 2 subscales should be cautiously interpreted. Further development and investigation with a wider range of occupations to improve the reliability and validity of the questionnaire could be helpful.

\section{Conclusions}

The findings suggest that different job types need different sources of social support in the workplace. It is recommended that nurse managers assess nurses' perception of JCQ job type before exploring programs to promote social support in hospitals to help reduce the stress level among nurses. Proactive steps by nurse managers to increase workplace social support might lead to an increase in the intent to stay and reduce nursing turnover in hospitals and possibly other settings.

Acknowledgments: The authors would like to thank all the registered nurses who cooperated in this study. This study was partially supported by the China Medical Board (CMB) and the Faculty of Public Health, Mahidol University.

\section{References}

1) Buerhaus PI, Donelan K, Ulrich BT, Norman L, Dittus R. Is the shortage of hospital registered nurses getting better or worse? Findings from two recent national survey of RNs. Nursing Economics 2005; 23: 61-96.

2) Ulrich BT, Buerhaus PI, Donelan K, Norman L, Dittus R. How RNs view the work environment: results of a national survey of registered nurses. J Nurs Adm 2005; 35: 389-96.

3) Flinkman M, Leino-Kilpi H, Salanterä S. Nurses' intention to leave the profession: integrative review. J Adv Nurs 2010; 66: 1422-34.

4) Hayes LJ, O'Brien-Pallas L, Duffield C, et al. Nurse turnover: a literature review- an update. Int $\mathrm{J}$ Nurs Stud 2012; 49: 887-905.

5) Sawangdee K. Situation of registered nurses in Thailand. J Health System Research 2008; 2: 40-6 (in Thai).

6) Kaewboonchoo O, Saipech T, Chandanasotthi P, Arphorn S. Mental health status among Thai hospital nurses. J Med Assoc Thai 2009; 92 (suppl): S83-7.

7) Price JL, Mueller CW. Professional turnover: the Case of Nurses. Jamaica, NY: Spectrum Publications, 1981.

8) Sourdif J. Predictors of nurses' intent to stay at work in a university health center. Nurs Health Sci 2004; 6: 59-68.

9) Hayes LJ, O'Brien-Pallas L, Duffield C, et al. Nurse turnover: a literature review. Int J Nurs Stud 2006; 43: 237-63.

10) Rees D, Cooper CL. Occupational stress in health service workers in the U.K. Stress Med 1992; 8: 79-90.

11) Wheeler HH. Nurse occupational stress research 2: definition and conceptualization. Br J Nurs 1994; 3: 527-34.

12) Joshua-Amdi M. Recruitment and retention in the NHS: a study in motivation. Nurs Manag 2003; 9: 14-9.

13) Karesek R, Theorell T, eds. Healthy Work-Stress, Productivity, and the Reconstruction of Working Life. New York: Basic Books, 1990.

14) Karasek RA, Brisson C, Kawakami N, Houtman I, Bongers P, Amick B. The Job Content Questionnaire (JCQ): An instrument for internationally comparative assessments of psychosocial job characteristics. J Occup Health Psychol 1998; 3: 322-55.

15) Kuper H, Marmot M. Job strain, job demands, decision latitude, and risk of coronary heart disease within the Whitehall II study. J Epidemiol Community Health 2003; 57: 147-53.

16) Lee S, Colditz G, Berkman L, et al. A prospective study of job strain and coronary heart disease in US women. Int J Epidemiol 2003; 31: 1147-53.

17) Kivimaki M, Leino-Arjas $P$, Luukkonen $R$, et al. Work stress and risk of cardiovascular mortality: prospective cohort study of industrial employees. 
BMJ 2002; 325: 857 .

18) Hoogendoorn WE, Bongers PM, de Vet $\mathrm{HC}$, et al. Psychosocial work characteristics and psychological strain in relation to low-back pain. Scan J Work Environ Health 2001; 27: 258-67.

19) Choobineh A, Movahed M, Tabatabaie $\mathrm{SH}$, Kumashiro M. Percieved demand and musculoskeletal disorders in operating room nurses of Shiraz city hospitals. Ind Health 2010; 48: 74-84.

20) Hasselhorn HM, Conway PM, Widerszal-Bazyl M, et al. Contribution of job strain to nurses' consideration of leaving the profession-results from the longitudinal European nurses' early exit study. SJWEH Suppl 2008; 6: 75-82.

21) Urakawa K, Yokoyama K. Sense of coherence (SOC) may reduce the effects of occupational stress on mental health status among Japanese Factory workers. Ind Health 2009; 47: 503-8.

22) Lavoie-Tremblay M, O'Brien-Pallas L, Gélinas C, Desforges N, Marchionni C. Addressing the turnover issue among new nurses from a generational viewpoint. J Nurs Manag 2008; 16: 724-33.

23) Chiu YL, Chung RG, Wu CS, Ho CH. The effects of job demands, control, and social support on hospital clinical nurses' on intention to turn over. Appl Nurs Res 2009; 22: 258-63.

24) Phakthongsuk P, Apakupakul N. Psychometric properties of the Thai version of the 22-item and 45-item Karasek Job Content Questionnaire. IJOMEH 2008; 21: 331-44.

25) SPSS. Base 11.5 Application guide, SPSS Inc, Chicago, 2003.

26) Sein MM, Howteerakul N, Suwannapong N, Jirachewee J. Job strain among rubber-glove factory workers in central Thailand. Ind Health 2010; 48: 503-10.

27) Li J, Yang W, Liu P, Xu Z, Cho S. Psychometric Evaluation of the Chinese (Mainland) version of the Job Content Questionnaire: a study in university hospital. Ind Health 2004; 42: 260-7.

28) Shen HC, Cheng Y, Tsai PJ, Lee SS, Guo YL. Occupational stress in nurses in psychiatric institutions in Taiwan. J Occup Health 2005; 47: 218-25.

29) Fisher ML, Hinson N, Deets C. Selected predictors of registered nurses' intent to stay. J Adv Nurs 1994; 20: 950-7.

30) Lynn MR, Redman RW. Faces of the nursing shortage: influences on staff nurses' intentions to leave their positions or nursing. J Nurs Adm 2005; 35: 264-70.

31) Nedd N. Perceptions of empowerment and intent to stay. Nursing Economics 2006; 2: 13-8.

32) Lacey SR, Cox KS, Lorfing KC, Teasley SL, Carroll CA, Sexton K. Nursing support, workload, and intent to stay in Magnet, Magnet-aspiring, and non Magnet hospital. J Nurs Adm 2007; 37: 199-205.

33) Chen HC, Chu CI, Wang YH, Lin LC. Turnover factors revisited: a longitudinal study of Taiwanbased staff nurses. Int J Nurs Stud 2008; 45 : 277-85.

34) Strachota E, Normandin P, O'Brien-Pallas N, Ciary M, Krukow B. Resons registered nurses leave or change employment status. J Nurs Adm 2003; 33: 111-5.

35) McCarthy VJC, Power S, Greiner BA. Perceived occupational stress in nurses working in Ireland. Occup Med 2010; 60: 604-10.

36) Constable JF, Russell DW. The effect of social support and the work environment upon burnout among nurses. J Human Stress 1986; 12: 20-6.

37) Bland J, Altman D. Statistics notes: Cronbach's alpha. BMJ 1997; 314: 275.

38) Streiner D. Starting at the beginning: an introduction to coefficient alpha and internal consistency. J Pers Assess 2003; 80: 99-103. 